\title{
PENGARUH UKURAN PEMERINTAH DAERAH, TINGKAT KEKAYAAN DAERAH, TINGKAT KETERGANTUNGAN DAERAH, BELANJA MODAL DAN TEMUAN AUDIT BPK TERHADAP AKUNTABILITAS KINERJA PEMERINTAH DAERAH (STUDI PADA PEMERINTAH KABUPATEN/KOTA DI PROVINSI JAMBI)
}

\author{
Kusnadewi Lestari ${ }^{1)}$, Sri Rahayu ${ }^{2),}$ Yudi $^{3)}$ \\ 1)Alumni Magister Ilmu Akuntansi Pascasarjana Universitas Jambi Tahun 2019 \\ ${ }^{2 \& 3)}$ Dosen Pembimbing
}

\begin{abstract}
The Purpose of this research is to provide empirical evidence on the Effect of Local Government Size, Regional Wealth Levels, Regional Dependency Level, Capital Expenditures and Audit Findings of the Republic of Indonesia $B P K$ on the Performance Accountability of District / City Governments in Jambi Province. The population in this study were 11 districts / cities (9 districts and 2 cities) in Jambi Province in 2014-2017, the number of observations of this study was 44. The analytical method used was quantitative analysis, with panel data regression models using Eviews9. The results showed: (1) Local Government Size, Regional Wealth Level, Regional Dependency Level, Capital Expenditures and Audit Findings The Republic of Indonesia BPK had a simultaneous effect on the Performance Accountability of District / City Governments in Jambi Province, (2) Regional Government Measures partially affected Against the Performance Accountability of District / City Governments in Jambi Province, (3) Regional Wealth Levels have a partial effect on the Accountability of Performance of District / City Regional Governments in Jambi Province, (4) Regional Dependency has a partial effect on Accountability of District / City Government Performance in Jambi Province, (5) Capital Expenditure does not partially affect the Accountability of Performance of District / City Governments in Jambi Province, and (6) Audit Findings of the BPK RI have no partial effect on the Accountability of Performance of District / City Governments in Jambi Province.
\end{abstract}

Keywords : The Effect of Local Government Size, Regional Wealth Levels, Regional Dependency Level, Capital Expenditures, Audit Findings of the Republic of Indonesia BPK, evaluation of local goverment performance accountability.

\begin{abstract}
ABSTRAK
Penelitian ini bertujuan untuk memberikan bukti empiris Pengaruh Ukuran Pemerintah Daerah, Tingkat Kekayaan Daerah, Tingkat Ketergantungan Daerah, Belanja Modal dan Temuan Audit BPK RI terhadap Akuntabilitas Kinerja Pemerintah Daerah Kabupaten/Kota di Provinsi Jambi. Populasi dalam penelitian ini adalah 11 kabupaten/kota ( 9 kabupaten dan 2 kota ) pada Provinsi Jambi Tahun 2014-2017, jumlah pengamatan penelitian ini sebanyak 44. Metode analisis yang digunakan adalah analisis kuantitatif, dengan model regresi data panel dengan menggubakan Eviews9 . Hasil penelitian menunjukkan: (1) Ukuran Pemerintah Daerah, Tingkat Kekayaan Daerah, Tingkat Ketergantungan Daerah, Belanja Modal dan Temuan Audit BPK RI berpengaruh secara simultan terhadap Akuntabilitas Kinerja Pemerintah Daerah Kabupaten/Kota di Provinsi Jambi, (2) Ukuran Pemerintah Daerah berpengaruh secara parsial terhadap Akuntabilitas Kinerja Pemerintah Daerah Kabupaten/Kota di Provinsi Jambi, (3) Tingkat Kekayaan Daerah berpengaruh secara parsial terhadap Akuntabilitas Kinerja Pemerintah Daerah Kabupaten/Kota di Provinsi Jambi, (4) Tingkat Ketergantungan Daerah berpengaruh secara parsial terhadap Akuntabilitas Kinerja Pemerintah Daerah Kabupaten/Kota di Provinsi Jambi, (5) Belanja Modal tidak berpengaruh secara parsial terhadap Akuntabilitas Kinerja Pemerintah Daerah Kabupaten/Kota di Provinsi Jambi, dan (6) Temuan Audit BPK RI tidak berpengaruh secara parsial terhadap Akuntabilitas Kinerja Pemerintah Daerah Kabupaten/Kota di Provinsi Jambi.
\end{abstract}

Kata Kunci : Ukuran Pemerintah Daerah, Tingkat Kekayaan Daerah, Tingkat Ketergantungan Daerah, Belanja Modal, Temuan Audit BPK RI, Akuntabilitas Kinerja. 


\section{PENDAHULUAN}

\subsection{Latar Belakang}

Indonesia memulai desentralisasi dan memasuki era otonomi daerah setelah dikeluarkannya Undangundang Nomor 22 tahun 1999 tentang otonomi daerah, sebagaimana telah diubah dengan Undang-undang Nomor 32 tahun 2004, tentang pemerintah daerah dan selanjutnya diubah kembali dengan Undang-undang Nomor 23 tahun 2014, tentang Pemerintah Daerah dan tentang Perimbangan Keuangan antara Pemerintah Pusat dan Daerah menegaskan bahwa pemerintah daerah memiliki kewenangan untuk mengatur dan mengurus sendiri urusan pemerintahan berdasarkan asas otonomi (Qowi dan Prabowo, 2017).

Reformasi birokrasi otonomi daerah menurut Ara (2016) telah membawa perubahan bagi sistem administrasi keuangan Negara dengan ditetapkannya paket Undang-Undang Keuangan Negara, yaitu Undang-Undang Nomor 17 Tahun 2003 tentang Keuangan Negara, Undang-Undang Nomor 1 Tahun 2004 tentang Perbendaharaan Negara dan UndangUndang Nomor 15 Tahun 2004 tentang Pemeriksaan Keuangan Negara. Paket undang-undang tersebut menginginkan adanya transparansi dan akuntabilitas dalam pengelolaan keuangan daerah dalam rangka mewujudkan good governance.

Paket undang-undang keuangan negara salah satunya menyatakan bahwa kepala daerah menyampaikan rancangan peraturan daerah, tentang pertanggungjawaban pelaksanaan Anggaran Pendapatan Belanja Daerah (APBD) kepada Dewan Perwakilan Rakyat Daerah (DPRD) dan laporan keuangan yang telah diperiksa oleh Badan Pemeriksa Keuangan Republik Indonesia (BPK RI). Standar atau acuan kapan suatu daerah dikatakan mandiri, efektif dan efisien, serta akuntabel perlu ditetapkan dalam suatu sistem pengelolaan keuangan daerah terkait dengan pengelolaan APBD.

Anggaran daerah yang dikenal dengan APBD merupakan kerangka kebijakan public yang memuat hak dan kewajiban pemda yang tercermin dalam pendapatan, belanja dan pembiayaan yang dinyatakan dalam satuan moneter dan disusun berdasarkan pendekatan prestasi kerja yang akan dicapai. APBD merupakan wujud pengelolaan keuangan daerah yang ditetapkan setiap tahun oleh Kepala Daerah dengan Peraturan daerah dan disusun berpedoman pada visi dan misi serta rencana kerja pemerintah yang disusun secara objektif dan melibatkan seluruh komponen yang ada dalam pemerintahan. Azlina dan Riantarno (2011) menyatakan dengan adanya sistem tersebut pemda akan dapat mengukur kinerja keuangannya yang tercermin dalam APBD.

Pengukuran kinerja dalam penelitian ini menggunakan akuntabilitas kinerja, yang dilakukan dengan menerapkan Sistem Akuntabilitas Kinerja
Instansi Pemerintah (SAKIP) yang merupakan sarana untuk melaporkan penyelenggaraan pemerintahan apakah sudah terlaksana dengan efektif, efisien, bersih, akuntabel, dan tepat sasaran. Setiap pemerintah daerah harus menerapkan SAKIP dan melaporkan kinerjanya melalui Laporan Akuntabilitas Kinerja Instansi Pemerintah (LAKIP) yang akan dievaluasi oleh Aparat Pengawasan Internal Pemerintah (APIP) di bawah koordinasi Kementerian Pendayagunaan Aparatur Negara Reformasi Birokrasi (Kemenpan-RB) sebagai pihak yang bertugas melakukan penguatan akuntabilitas kinerja instansi pemerintah (Nurdin, 2015). Hasil evaluasi akuntabilitas kinerja dikelompokkan dalam 7 kategori, yaitu kategori AA (sangat memuaskan), A (memuaskan), BB (sangat baik), B (baik), CC (cukup), C (kurang), dan D (sangat kurang) (Kemenpan-RB, 2015). Akuntabilitas Kinerja adalah perwujudan kewajiban instansi pemerintah untuk mempertanggungjawabkan keberhasilan pelaksanaan Program dan Kegiatan yang telah diamanatkan para pemangku kepentingan dalam rangka mencapai misi organisasi secara terukur dengan sasaran/target Kinerja yang telah ditetapkan melalui laporan kinerja instansi pemerintah yang disusun secara periodik (Perpres No 29 Tahun 2014).

Kementerian Pendayagunaan Aparatur Negara dan Reformasi Birokrasi. Asman Abnur menjelaskan bahwa regional satu wilayah Sumatera, Banten, dan Jawa Barat menunjukkan bahwa sebanyak 172 pemerintah kabupaten/kota telah dievaluasi Kementerian Pendayagunaan Aparatur Negara dan Reformasi Birokrasi. Beliau menjelaskan bahwa satu daerah mendapat predikat $A$ dan 3 pemerintah kabupaten kota mendapat predikat BB, 17 predikat B, 81 predikat CC, 69 berpredikat C, dan satu kabupaten dengan predikat $\mathrm{D}$. hal tersebut menunjukkan bahwa akuntabilitas kinerja ini belum sepenuhnya mendapatkan perhatian yang memadai dari pemerintah daerah. dengan demikian akuntabilitas kinerja menjadi topik yang menarik untuk dikaji lebih lanjut (KemenPAN\&RB,2016).

Akuntabilitas kinerja pemerintah daerah di Provinsi Jambi tahun 2017 telah ada peningkatan dari 8 kabupaten yang masih berpredikat "CC" sekarang hanya menjadi 4 kabupaten saja yaitu Kabupaten Tebo, Kabupaten Muaro Jambi, Kabupaten Tanjung Jabung Timur, dan Tanjung Jabung Barat. Namun demikian, nilai keseluruhan hasil evaluasi akuntabilitas kinerja di Provinsi Jambi masih berpredikat "CC" (cukup) dengan nilai SAKIP sebesar 58,70 ditahun 2017 hanya naik sedikit dari tahun 2016 yakni sebesar 58,29 dan sangat turun dari tahun 2015 yakni dengan nilai sebesar 59,36 untuk mendapat predikat "B" (Baik) Pemerintah Daerah Provinsi Jambi setidaknya harus melewati nilai 60. Berikut hasil evaluasi akuntabilitas kinerja 
pemerintah daerah kabupaten/kota di provinsi Jambi pada tahun 2014-2017 tersaji dalam gambar 1.2 berikut:

\section{Gambar 1.}

\section{Hasil Evaluasi Akuntabilitas Kinerja Pemerintah} Daerah di Provinsi Jambi

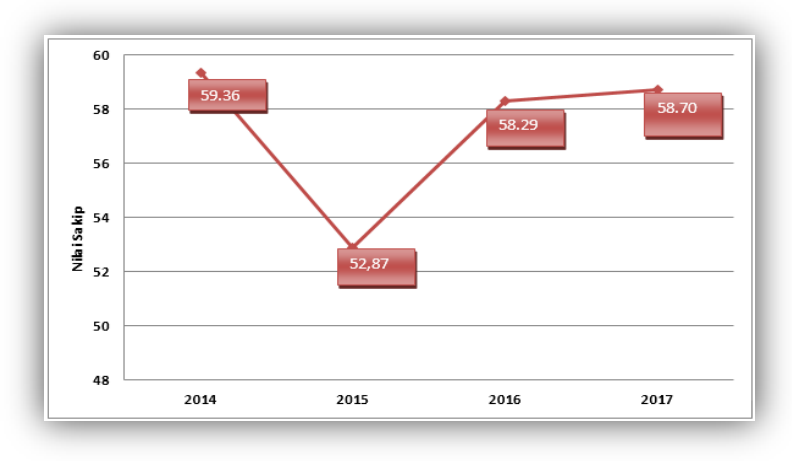

Sumber: LKJ Provinsi Jambi 2017 data diolah.

Permasalahan akuntabilitas kinerja pemerintah daerah Kabupaten/Kota di Provinsi Jambi tersebut merupakan kajian yang sangat menarik dan masih relatif jarang dilakukan penelitian. Melihat fenomena tersebut menurut Kementrian Pendayagunaan Aparatur Negara dan Reformasi Birokrasi (Kemenpan-RB) factor-faktor yang mempengaruhi akuntabilitas kinerja pemerintah daerah yakni sasaran yang ditetapkan tidak berorientasi pada hasil, ukuran keberhasilan tidak jelas dan terukur, kegiatan yang ditetapkan tidak berkaitan dengan sasaran lalu yang terakhir perincian kegiatan tidak sesuai dengan tujuan. Hal tersebut dapat dilihat dalam LAKIP yang menggambarkan kinerja yang dicapai suatu instansi pemerintah atas pelaksanaan program dan kegiatan yang dibiayai APBN/APBD karena faktor-faktor tersebut tercatut didalamnya (PermenPAN-RB No. 29/2010/P12).

APBD merupakan suatu kesatuan dari Pendapatan, Belanja, dan Pembiayaan (Penerimaan Pembiayaan dan Pengeluaran Pembiayaan). Sumber penerimaan daerah berasal dari pendapatan dan penerimaan pembiayaan yang merupakan sumber daya keuangan yang akan digunakan dalam menjalankan program/kegiatan, sedangkan pengeluran daerah berupa belanja dan pengeluaran pembiayaan yang merupakan input yang digunakan untuk menjalankan program/kegiatan. Untuk dapat menjalankan program/kegiatan yang disusun dalam APBD guna mencapai tujuan yang ingin dicapai, Pemerintah daerah bertanggung jawab untuk mengelola sumber-sumber penerimaan daerah dan juga asset yang sudah dimiliki daerah (Permendagri No.13 Tahun 2006).

Pemerintah daerah yang memiliki total aset yang besar dituntut untuk melakukan transparansi atas pengelolaannya sebagai bentuk akuntabilitas terhadap publik (Setyaningrum dan Syafitri, 2012). Menurut Mustikarini dan Fitriasari (2012) Ukuran Pemda yang mana diproksikan dengan total asset berpengaruh secara signifikan terhadap kinerja pemda, sejalan dengan penelitian Sutaryo dan Suharyanto (2016) total asset juga mempengaruhi akuntabilitas kinerja pemda. Sedangkan penelitian Muhammad Din et al (2017) menyatakan total asset tidak berpengaruh terhadap akuntabilitas pelaporan keuangan pemda. Pemerintah daerah juga memiliki sumber terbesar penerimaan yaitu berasal dari pendapatan salah satunya ialah pendapatan asli daerah. Penelitian Nurdin (2015) mengukur karakteristik pemda dilihat dari tingkat kekayaan daerah berpengaruh positif terhadap akuntabilitas kinerja pemerintah Kabupaten/Kota. Namun berbeda dengan penelitian Sutaryo dan Suharyanto (2016) yang menyatakan bahwa PAD tidak berpengaruh terhadap akuntabilitas kinerja pemda. Besarnya PAD yang diperoleh pemda tidak menjadi acuan bahwa pemda tersebut dapat mengelola PAD nya dengan baik hal itu dapat dilihat dari kinerja pemda itu sendiri.

Penelitian oleh Juweny (2016) dan Sudarsana dan Rahardjo (2013) mengukur tingkat ketergantungan daerah pada pemerintah pusat menggunakan Dana Alokasi Umum (DAU) yang diterima pemda terhadap kinerja pemda berpengaruh positif dan signifikasi. Sedangkan Nurdin (2015) menyatakan hal yang sebaliknya tingkat ketergantungan pada Pemerintah Pusat berpengaruh negatif terhadap akuntabilitas kinerja Pemerintah Kabupaten/Kota. Besarnya DAU yang diterima pemda tidak menjamin akan akuntabilitas kinerja, karena berjalannya otonomi daerah, potensi yang didapatkan pemda sebenarnya bisa mengelola keuangannya lebih baik tanpa harus bergantung DAU yang besar kepada pemerintah pusat.

Penelitian Nurdin (2015) menyatakan belanja daerah tidak berpengaruh terhadap akuntabilitas kinerja pemerintah kabupaten/kota. Dimana ini disebabkan karena lemahnya system perencanaan dan penganggaran pemda sehingga sering didapati ketidakcocokan antara program/kegiatan dengan output/outcome yang dihasilkan. Ini mengakibatkan belanja yang telah terealisasi tidak berakibat pada tercapainya tujuan dan sasaran yang telah direncanakan. Sedangkan pada penelitian Nurina (2016) menyatakan belanja modal berpengaruh terhadap akuntabilitas kinerja instansi pemerintah pada kantor Pemerintah Kota Banda Aceh. Ara et al (2016) juga menyatakan bahwa belanja modal berpengaruh positif.

Penelitian Muhammad Din et al (2017), dan Harumiati (2014), membuktikan bahwa tindak lanjut hasil pemeriksaan (temuan audit) berpengaruh positif terhadap akuntabilitas kinerja pemerintah daerah. Sedangkan Nurdin (2015) didalam penelitiannya mengemukakan bahwa temuan audit tidak berpengaruh terhadap akuntabilitas kinerja Pemerintah Kabupaten/Kota. Sebagai perwujudan akuntabilitas dan transparansi atas pengelolaan keuangan Negara yang 
dilaksanankan Pemda, maka Pemda wajib menyusun Laporan Keuangan Pemerintah Daerah (LKPD) yang kemudian akan diaudit oleh institusi pemeriksaan yang bebas dan mandiri, dalam hal ini adalah BPK RI.

Mengacu kepada UU No.15 tahun 2004 tentang Pemeriksaan Pengelolaan dan Tanggung Jawab Keuangan Negara bahwa untuk mendukung keberhasilan penyelenggaraan pemerintahan negara, keuangan negara wajib dikelola secara tertib, taat pada peraturan perundang-undangan, efisien, ekonomis, efektif, transparan, dan bertanggung jawab dengan memperhatikan rasa keadilan dan kepatutan dan untuk mewujudkan pengelolaan keuangan negara, perlu dilakukan pemeriksaan berdasarkan standar pemeriksaan oleh Badan Pemeriksa Keuangan yang bebas dan mandiri. Pemeriksaan keuangan negara dilakukan oleh Badan Pemeriksa Keuangan (BPK). Hasil dari pemeriksaan yang dilakukan BPK tersebut berupa temuan audit. Semakin banyak temuan audit menunjukkan bahwa pengelolaan keuangan dari pemda tersebut, yang merupakan salah satu komponen penilaian SAKIP kurang baik, yang pada akhirnya akan berpengaruh terhadap kinerja pemda tersebut (Mustikarini dan Fitriasari, 2012).

Penelitian tentang akuntabilitas kinerja pemerintah daerah diteliti oleh Rizani Mairi et al (2014) yang bertujuan untuk menganalisis akuntabilitas kinerja di instansi pemerintah. Penelitiannya menjelaskan bahwa akuntabilitas kinerja di Indonesia adalah fenomena yang datang dari permintaan masyarakat mulai diartikulasikan dari awal era reformasi pada tahun 1998. Sebagai implementasi akuntabilitas kinerja konsep dalam tata kelola, setiap lembaga pemerintah memiliki kewajiban untuk mengungkapkan laporan setelah akhir tahun fiskal, dalam bentuk Laporan Akuntabilitas Kinerja Instansi Pemerintah (LAKIP). Penelitiannya menjelaskan bahwa akuntabilitas kinerja pemerintah daerah belum optimal karena terdapat beberapa hambatan bagi lembaga untuk menyajikan Laporan Akuntabilitas Kinerja Instansi Pemerintah. Sutaryo dan Suharyanto (2016), juga melakukan penelitian tentang akuntabilitas dan hasilnya menyatakan bahwa PAD yang dilaporkan dalam LRA tidak mempengaruhi akuntabilitas kinerja pemerintah daerah tetapi asset yg diukur dalam ukuran pemerintah daerah berpengaruh terhadap akuntabilitas kinerja pemerintah daerah, lalu Fontanella dan Rosietta (2014) mengaitkan pengaruh desentralisasi fiscal dan kinerja terhadap akuntabilitas pelaporan keuangan pemda di Indonesia.

\subsection{Rumusan Masalah}

Berdasarkan permasalahan tersebut, maka dapat dirumuskan pertanyaan penelitian sebagai berikut:
1) Bagaimanakah pengaruh ukuran Pemerintah Daerah, Tingkat Kekayaan Daerah, Tingkat Ketergantungan Daerah, Belanja Modal dan Temuan Audit BPK RI secara Simultan terhadap Akuntabilitas Kinerja Pemerintah Daerah Kabupaten/Kota di Provinsi Jambi?

2) Bagaimanakah Pengaruh Ukuran Pemerintah Daerah secara Parsial terhadap Akuntabilitas Kinerja Pemerintah Daerah Kabupaten/Kota di Provinsi Jambi?

3) Bagaimanakah Pengaruh Tingkat Kekayaan Daerah secara Parsial terhadap Akuntabilitas Kinerja Pemerintah Daerah Kabupaten/Kota di Provinsi Jambi ?

4) Bagaimanakah Pengaruh Tingkat Ketergantungan Daerah secara Parsial terhadap Akuntabilitas Kinerja Pemerintah Daerah Kabupaten/Kota di Provinsi Jambi ?

5) Bagaimanakah Pengaruh Belanja Modal secara Parsial terhadap Akuntabilitas Kinerja Pemerintah Daerah Kabupaten/Kota di Provinsi Jambi ?

6) Bagaimanakah Pengaruh Temuan Audit BPK RI secara Parsial terhadap Akuntabilitas Kinerja Pemerintah Daerah Kabupaten/Kota di Provinsi Jambi ?

\section{KAJIAN PUSTAKA, KERANGKA PEMIKIRAN DAN HIPOTESIS}

\subsection{Kajian Pustaka}

\subsubsection{Sterwardship Theory}

Grand theory yang mendasari penelitian ini adalah bagian dari agency theory yaitu stewardship theory. Donaldson et.al. (1997) dalam penelitiannya menemukan faktor yang membedakan antara Agency Theory dan Stewardship Theory. Teori stewardship menggambarkan situasi dimana manajemen tidaklah termotivasi oleh tujuan-tujuan individu tetapi lebih ditujukan pada sasaran hasil utama mereka untuk kepentingan organisasi. Teori tersebut mengasumsikan adanya hubungan yang kuat antara kepuasan dan kesuksesan organisasi. Kesuksesan organisasi menggambarkan maksimalisasi utilitas kelompok principals dan manajemen. Maksimalisasi utilitas kelompok ini pada akhirnya akan memaksimumkan kepentingan individu yang ada dalam kelompok organisasi.

Implikasi teori stewardship dalam penelitian ini yaitu stewards dalam hal ini adalah para pengelola anggaran di Kabupaten/Kota di Provinsi Jambi sehingga dapat dipercaya untuk bertindak sesuai dengan kepentingan publik diharapkan akan bekerja dengan sebaik-baiknya untuk kepentingan principal yaitu masyarakat dengan melaksanakan tugas dan 
fungsinya dengan tepat, merencanakan dan melaksanakan anggaran yang diamanahkan kepadanya, dengan demikian tujuan pengelolaan anggaran dapat tercapai secara maksimal. Untuk melaksanakan tanggungjawab tersebut maka stewards diharapkan meningkatkan kinerjanya dan menggunakan keahlian Sumber Daya Manusianya dengan memanfaatkan Teknologi Informasi, Komitmen semua pegawai yang terlibat dalam pengelolaan anggaran sehingga diharapkan dapat mencapai pengelolaan anggaran yang makin efektif.

\subsubsection{Akuntabilitas Kinerja}

Akuntabilitas merupakan salah satu unsur dari perwujudan good governance yang sedang dilakukan di Indonesia, karena menurut Suyanto (2010) akuntabilitas merupakan kunci dari konsep good governance, untuk mendukung hal tersebut diperlukan pengembangan dan penerapan sistem pertanggungjawaban yang tepat, jelas, dan terukur, dan berlangsung secara berdaya guna, berhasil guna, bersih dan bertanggungjawab serta bebas dari kolusi, korupsi, dan nepotisme. Akuntabilitas Kinerja Instansi Pemerintah adalah perwujudan kewajiban suatu instansi pemerintah untuk mempertanggungjawabkan keberhasilan dan kegagalan pelaksanaan misi organisasi dalam mencapai sasaran dan tujuan yang telah ditetapkan melalui sistem pertenggungjawaban secara periodik (BPKP, 2007).

Sistem Akuntabilitas Kinerja Instansi Pemerintah (SAKIP) adalah instrumen yang digunakan instansi pemerintah dalam memenuhi kewajiban untuk mempertanggung jawabkan keberhasilan dan kegagalan pelaksanaan misi organisasi. SAKIP terdiri dari berbagai komponen yang merupakan satu kesatuan yaitu perencanaan strategis, perencanaan kinerja, pengukuran kinerja dan pelaporan kinerja (LAN-RI, 2003). Selain itu, SAKIP merupakan penerapan manajemen kinerja pada sektor publik yang sejalan dan konsisten dengan penerapan reformasi birokrasi, yang berorientasi pada pencapaian outcomes dan upaya untuk mendapatkan hasil yang lebih baik. Hasil dari pelaksanaan evaluasi selesai secara keseluruhan, KEMENPAN \& RB memberikan peringkat nilai dengan sebutan: AA (sangat memuaskan), A (memuaskan), BB (sangat baik), B (baik), CC (cukup), C (kurang), dan D (sangat kurang) (KEMENPAN \& RB, 2015).

\subsubsection{Ukuran Pemerintah Daerah}

Ukuran pemerintah daerah menunjukkan seberapa besar pemerintahan daerah. Dengan jumlah aset/pegawai/ produktifitas yang lebih besar sehingga diharapkan memiliki kinerja keuangan yang lebih baik daripada daerah yang lebih kecil (Patrick ,2007).

\subsubsection{Tingkat Kekayaan Daerah}

Tingkat kekayaan Pemda diproksikan dengan pendapatan asli daerah (PAD). Menurut UndangUndang No. 33 Tahun 2004 PAD adalah sumber keuangan daerah yang digali dari wilayah daerah yang bersangkutan yang terdiri dari hasil pajak daerah, hasil retribusi daerah, hasil pengelolaan kekayaan daerah yang dipisahkan dan lain-lain pendapatan asli daerah yang sah.

\subsubsection{Tingkat Ketergantungan Daerah}

Tingkat ketergantungan terhadap dana transfer dari pemerintah pusat di Indonesia tercermin dari besarnya dana perimbangan yang diberikan. Definisi dana perimbangan menurut Undang- Undang Nomor 33 tahun 2004 adalah dana yang bersumber dari Anggaran Pendapatan dan Belanja Negara yang dialokasikan kepada daerah untuk mendanai kebutuhan daerah dalam rangka pelaksanaan desentralisasi. Robbin dan Austin (1986) memaparkan bahwa intergovernmental revenue merepresentasikan tingkat ketergantungan pemerintah daerah. Tingkat ketergantungan yang tinggi cenderung meningkatkan tingkat pengungkapan. Hal ini disebabkan adanya kepentingan bagi pemerintah pusat untuk memantau apa yang dilakukan pemerintah daerah dan tingkat pencapaian kinerja atas alokasi dana yang telah diberikan oleh Pemerintah Pusat.

\subsubsection{Belanja Modal}

Menurut Permendagri No. 13 Tahun 2006 belanja modal adalah total belanja yang digunakan untuk pengeluaran yang dilakukan dalam rangka pembelian/pengadaan atau pembangunan aset tetap berwujud yang mempunyai nilai manfaat lebih dari 12 (dua belas) bulan untuk digunakan dalam kegiatan pemerintahan, seperti dalam bentuk tanah, peralatan dan mesin, gedung dan bangunan, jalan, irigasi dan jaringan, dan aset tetap lainnya. Belanja modal adalah pengeluaran anggaran untuk perolehan aset tetap berwujud yang memberi manfaat lebih dari satu periode akuntansi.

\subsubsection{Temuan Audit BPK}

Berdasarkan Undang-Undang No.15 tahun 2004 tentang Pemeriksaan Pengelolaan dan Tanggung Jawab Keuangan Negara menyatakan bahwa untuk mendukung keberhasilan penyelenggaraan pemerintahan negara, keuangan negara wajib dikelola secara tertib, taat pada peraturan perundang-undangan, efisien, ekonomis, efektif, transparan, dan bertanggung jawab dengan memperhatikan rasa keadilan dan kepatutan dan untuk mewujudkan pengelolaan keuangan negara, perlu dilakukan pemeriksaan berdasarkan standar pemeriksaan oleh Badan Pemeriksa Keuangan yang bebas dan mandiri. Pemeriksaan keuangan negara dilakukan oleh Badan Pemeriksa 
Keuangan (BPK) dan terdiri dari pemeriksaan keuangan, pemeriksaan kinerja dan pemeriksaan dengan tujuan tertentu. Hasil dari pemeriksaan yang dilakukan BPK tersebut berupa opini, temuan, kesimpulan atau dalam bentuk rekomendasi.

\subsection{Penelitian Terdahulu}

Riantoro dan Azlina (2011), melakukan penelitian yang bertujuan untuk menganalisis factorfaktor yang mempengaruhi akuntabilitas kinerja instansi pemerintah memperoleh hasil bahwa kepatuhan pada perundang-undangan berpengaruh positif dan signifikan terhadap akuntabilitas kinerja instansi.

Mustikarini dan Fitriasari (2012), Hasil penelitian menunjukkan bahwa ukuran, tingkat kekayaan dan tingkat kertergantungan pada pusat berpengaruh positif terhadap kinerja pemerintah, sedangkan belanja modal dan temuan audit berpengaruh negatif terhap kinerja pemerintah daerah.

Sudarsana dan Rahardjo (2013), Berdasarkan hasil analisis regresi menunjukkan bahwa ukuran pemerintah daerah dengan proksi total aset, variabel tingkat ketergantungan daerah kepada pemerintah pusat dengan proksi DAU dibanding total pendapatan dan belanja modal dengan proksi belanja modal dibanding total realisasi belanja terbukti tidak berpengaruh secara signifikan terhadap skor kinerja Pemda kabupaten/kota. Sedangkan temuan audit BPK dengan proksi temuan audit dibanding total anggaran belanja dan tingkat kekayaan daerah dengan proksi PAD dibanding total pendapatan berpengaruh secara signifikan terhadap skor kinerja Pemda kabupaten/kota di Indonesia.

Fontanella dan Rossieta (2014), melakukan penelitian yang bertujuan untuk menganalisis pengaruh desentralisasi fiscal dan kinerja terhadap akuntabilitas pelaporan keuangan pemerintah di Indonesia yang menemukan bahwa desentralisasi fiscal dalam bentuk tingkat kemandirian daerah dan kinerja penyelenggaraan pemerintah berpengaruh positif terhadap kemungkinan tingginya akuntabilitas pelaporan keuangan pemerintah daerah, sedangkan tingkat ketergantungan pada pemerintah pusat berpengaruh negative terhadap akuntabilitas pelaporan keuangan (opini audit).

Armaja et al (2015), Hasil penelitiannya menunjukkan bahwa kekayaan daerah dan anggaran perimbangan (rasio ketergantungan daerah) berpengaruh negatif terhadap kinerja pemerintah daerah sedangkan belanja daerah berpengaruh positif terhadap kinerja keuangan kabupaten/kota di Aceh.

Nurdin (2015), Hasil dari penelitiannya menyebutkan bahwa hanya tingkat kekayaan pemda yang berpengaruh terhadap akuntabilitas pemda sedangkan temuan audit, belanja daerah dan ketergantungan memiliki pengaruh negative terhadap akuntabilitas kinerja pemda. Ara (2016), Hasil penelitiannya menemukan bahwa (1) tingkat kekayaan pemerintah daerah berpengaruh positif terhadap kinerja pemerintah daerah, artinya bahwa tingkat kekayaan daerah yang semakin tinggi dan mampu digali serta dikelola oleh pemerintah daerah sebagai pembiayaan pembangunan dan pelayanan publik akan mendoorng kinerja pemerintah daerah yang baik; (2) Variabel tingkat ketergantungan daerah pada pemerintah pusat (DAU) berpengaruh positif terhadap kinerja pemerintah daerah. Tingkat keetrgantungan daerah berpengaruh dominan terhadap kinerja pemerintah daerah.

Sutaryo dan Suharyanto (2016), Hasil penelitiannya menunjukan bahwa level kapabilitas APIP mempengaruhi akuntabilitas kinerja pemerintah daerah, sedangkan jumlah auditor APIP tidak mempengaruhi. Lalu variable kontrol yang diuji menunjukkan letak geografis dan jumlah asset mempengaruhi akuntabilitas kinerja pemerintah daerah, sedangkan jumlah PAD tidak berpengaruh terhadap akuntabilitas kinerja pemerintah daerah.

Qowi dan Prabowo (2017), Hasil penelitiannya menjelaskan bahwa karakteristik pemerintah daerah yang diwakili tingkat kekayaan daerah, tingkat ketergantungan pada pemerintah pusat, belanja modal, dan temuan pemeriksaan BPK berpengaruh signifikan terhadap kinerja pemerintah daerah kabupaten/kota di Indonesia. Tingkat kekayaan berpengaruh signifikan positif terhadap kinerja pemerintah daerah. Muhammad Din et al (2017), Hasil penelitiannya menunjukkan bahwa tindak lanjut hasil pemeriksaan keuangan dapat mengurangi tingkat kerugian keuangan sehingga meningkatkan akuntabilitas pelaporan keuangan pemerintah daerah. Dengan demikian, hasil pemeriksaan (temuan audit) berpengaruh positif terhadap akuntabilitas pelaporan keuangan pemerintah daerah. Penelitiannya menjelaskan bahwa akuntabilitas bersama dengan transparansi adalah masalah utama bagi penyelenggara administrasi.

\subsection{Kerangka Pemikiran}

Berdasarkan dari penelitian terdahulu, maka pada penelitian ini dapat disusun kerangka pemikiran yang terdapat pada gambar model penelitian, sebagai berikut;

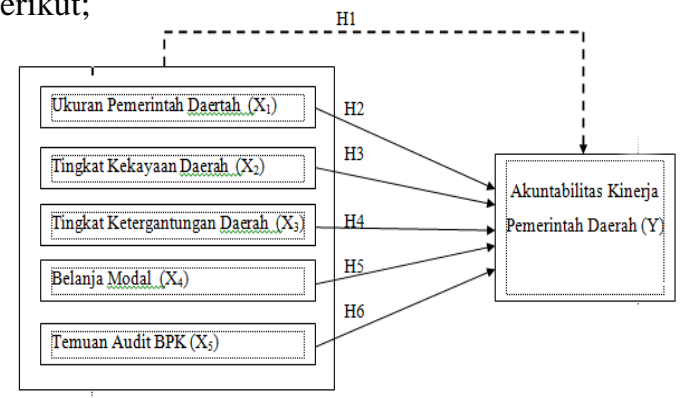




\subsection{Hipotesis} ini :

Adapun hipotesis yang diajukan dalam penelitian

$\mathrm{H}_{7}$ : Ukuran pemerintah daerah, tingkat kekayaan daerah, tingkat ketergantungan, belanja modal, dan temuan audit BPK berpengaruh terhadap akuntabilitas kinerja pemerintah daerah pada Kabupaten/Kota di Provinsi Jambi?

$\mathrm{H}_{2}$ : Ukuran pemerintah daerah berpangaruh terhadap akuntabilitas kinerja pemerintah daerah Kabupaten/Kota di Provinsi Jambi.

$\mathrm{H}_{3}$ : Tingkat kekayaan pemda berpengaruh terhadap akuntabilitas kinerja pemerintah daerah Kabupaten /Kota di Provinsi Jambi.

$\mathrm{H}_{4}$ : Tingkat ketergantungan berpengaruh terhadap akuntabilitas kinerja pemerintah daerah Kabupaten /Kota di Provinsi Jambi.

$\mathrm{H}_{5}$ : belanja modal berpengaruh terhadap akuntabilitas kinerja pemerintah daerah Kabupaten/Kota di Provinsi Jambi.

$\mathrm{H}_{6}$ : Temuan audit berpengaruh terhadap akuntabilitas kinerja pemerintah daerah Kabupaten/Kota di Provinsi Jambi.

\section{METODOLOGI PENELITIAN}

\subsection{Populasi dan Sampel}

Populasi dalam penelitian ini adalah Ukuran Pemda, Tingkat Kekayaan Daerah, Tingkat Ketergantungan, Belanja Modal, dan Temuan Audit BPK terhadap Akuntabilitas Kinerja Pemerintah Daerah Kabupaten/Kota di Provinsi Jambi. Subjek penelitian dalam penelitian ini adalah seluruh Pemerintah Kabupaten/Kota di Provinsi Jambi. Keseluruhan pemerintah Kabupaten/Kota tersebut sebanyak 9 kabupaten dan 2 Kota.

\subsection{Variabel Penelitian}

\begin{tabular}{|l|l|l|}
\hline \multicolumn{1}{|c|}{ Variabel } & \multicolumn{1}{|c|}{$\begin{array}{c}\text { Defenisi / Konsep } \\
\text { Variabel }\end{array}$} & \multicolumn{1}{c|}{$\begin{array}{c}\text { Indikator } \\
\text { Pengukuran }\end{array}$} \\
\hline Ukuran & $\begin{array}{l}\text { Ukuran pemerintah } \\
\text { Pemerintah } \\
\text { Daerah }\left(\mathrm{X}_{1}\right)\end{array}$ & $\begin{array}{l}\text { sumber daya dan fasilitas } \\
\text { yang memadai untuk }\end{array}$ \\
$\begin{array}{l}\text { memberikan pelayanan } \\
\text { kepada masyarakat, } \\
\text { sehingga ukuran daerah } \\
\text { yang ditandai dengan } \\
\text { besarnya jumlah asset }\end{array}$ & $\begin{array}{l}\text { Size Ln dari Total } \\
\text { Aset Pemerintah } \\
\text { Pemda. } \\
\text { Dustikarini,2012) }\end{array}$ \\
\hline
\end{tabular}

\begin{tabular}{|c|c|c|}
\hline $\begin{array}{l}\text { Tingkat } \\
\text { Kekayaan } \\
\text { Daerah }\left(\mathrm{X}_{2}\right)\end{array}$ & $\begin{array}{lr}\text { Tingkat } & \text { Kekayaan } \\
\text { daerah dapat di ukur } \\
\text { dengan menggunakan } \\
\text { PAD ribandingkan } \\
\text { dengan total pendapatan } \\
\text { sebagai } & \text { proksi } \\
\text { pengukuran } & \text { tingkat } \\
\text { kekayaan } & \text { daerah. } \\
\text { (Nurdin,2015) } & \end{array}$ & $\begin{array}{c}\text { PAD } \\
\text { TKD = } \\
\text { Total } \\
\text { Pendapatan }\end{array}$ \\
\hline $\begin{array}{l}\text { Tingkat } \\
\text { Ketergantung } \\
\text { an } \\
\left(\mathrm{X}_{3}\right)\end{array}$ & $\begin{array}{l}\text { Tingkat ketergantungan } \\
\text { Daerah } \\
\text { (intergovernmental } \\
\text { revenue) adalah jenis } \\
\text { pendapatan Pemerintah } \\
\text { Daerah yang berasal dari } \\
\text { transfer pemerintah pusat } \\
\text { kepada Pemerintah } \\
\text { Daerah untuk membiayai } \\
\text { operasi pemerintah } \\
\text { daerah (Patrick, 2007). }\end{array}$ & $\begin{array}{l}\text { DAU } \\
\text { TKP }= \\
\text { Total } \\
\text { Pendapatan }\end{array}$ \\
\hline $\begin{array}{l}\text { Belanja } \\
\text { Modal } \\
\left(\mathrm{X}_{4}\right)\end{array}$ & $\begin{array}{lr}\begin{array}{l}\text { Kementrian } \\
\text { Republik }\end{array} & \begin{array}{r}\text { Keuangan } \\
\text { Indonesia }\end{array} \\
\text { melalui } & \text { Direktorat } \\
\text { Jendral } & \text { Perimbangan } \\
\text { Keuangan } & (2012) \\
\text { menyatakan rasio belanja } \\
\text { modal terhadap } & \text { total } \\
\text { belanja } & \text { daerah } \\
\text { mencerminkan } & \text { porsi } \\
\text { belanja daerah } & \text { yang } \\
\text { dibelanjakan } & \text { untuk } \\
\text { membiayai } & \text { belanja } \\
\text { modal. } & \end{array}$ & $\begin{array}{l}\text { Total BM } \\
\text { BM = } \\
\text { Toral } \\
\text { Realisasi Belanja }\end{array}$ \\
\hline $\begin{array}{ll}\text { Temuan } & \\
\text { Audit } & \text { BPK } \\
\left(\mathrm{X}_{5}\right) & \end{array}$ & $\begin{array}{l}\text { Pengukuran temuan } \\
\text { audit dapat dilihat dari } \\
\text { semakin banyaknya } \\
\text { tingkat temuan audit } \\
\text { pemerintah daerah maka } \\
\text { menunjukkan tingkat } \\
\text { efisiensi kinerja } \\
\text { pemerintah daerah yang } \\
\text { tidak baik. Konsisten } \\
\text { dengan penelitian yang } \\
\text { dilakukan Mustikarini } \\
\text { dan Fitria (2012). }\end{array}$ & $\begin{array}{l}\begin{array}{l}\text { Temuan Audit BPK } \\
\text { (dalam rupiah) }\end{array} \\
\text { TA }=\frac{\text { Realisasi }}{\text { Total }} \\
\text { belanja daerah }\end{array}$ \\
\hline $\begin{array}{l}\text { Akuntabilitas } \\
\text { Kinerja } \\
\text { Pemerintah } \\
\text { Daerah (Y) }\end{array}$ & 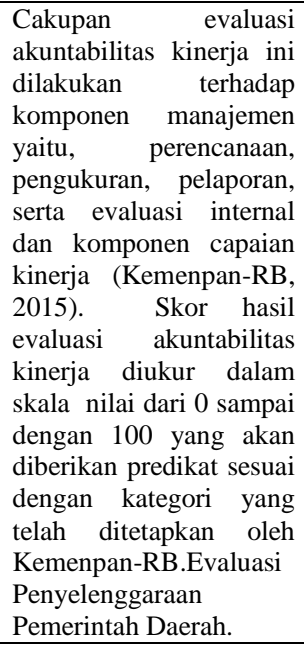 & $\begin{array}{c}\text { AKPD = Skor } \\
\text { akuntabilitas Kinerja } \\
\text { Pemda Kab/Kota } \\
\text { Prov. Jambi }\end{array}$ \\
\hline
\end{tabular}

Sumber : Data diolah. 


\section{HASIL DAN PEMBAHASAN}

\subsection{Hasil Penelitian}

\subsubsection{Analisis Statistik Deskriptif}

Hasil dari pengujian statistik deskriptif pada penelitian Pengaruh Ukuran Pemda, Tingkat Kekayaan, Tingkat Ketergantungan, belanja Modal dan Temuan Audit BPK terhadap Akuntabilitas Kinerja Pemerintah Darah (Studi pada Pemerintah Kabupaten/Kota di Provinsi jambi) ini dapat dilihat pada tabel 1 di bawah ini:

Tabel 1. Analisis Statistik Deskriptif

\begin{tabular}{lcccccc}
\hline \hline & Y & X1 & X2 & X3 & X4 & X5 \\
\hline \hline Mean & 54.10886 & 14.50864 & 15.25341 & 53.51182 & 24.62477 & 0.551364 \\
Med & 55.11500 & 14.57500 & 11.30000 & 54.65000 & 25.05000 & 0.295000 \\
Max & 61.91000 & 15.11000 & 50.37000 & 62.74000 & 45.14000 & 4.450000 \\
Mini & 32.81000 & 13.87000 & 3.500000 & 39.07000 & 10.67000 & 0.040000 \\
StDev & 5.835352 & 0.314048 & 11.11415 & 5.161086 & 6.789168 & 0.820007 \\
& & & & & & \\
Obs & 44 & 44 & 44 & 44 & 44 & 44 \\
\hline
\end{tabular}

Sumber: Data Olah Eview9

Hasil dari Tabel 1 di atas, dapat terlihat bahwa jumlah observasi yang digunakan dalam penelitian ini masing-masing berjumlah 44 data. Nilai minimum merupakan nilai terendah untuk setiap variabel, sedangkan nilai maksimum merupakan nilai tertinggi untuk setaip variabel dalam variabel. Nilai mean merupakan rata-rata dari setiap variabel yang diteliti. Deviasi standar merupakan sebaran data yang digunakan dalam penelitian yang mencerminkan data tersebut heterogen atau homogen yang sifatnya fluktuatif.

Data-data diperoleh dari variabel yang di teliti diantaranya Akuntabilitas Kinerja Pemda (Y), nilai minimum sebesar 32.81000, dan nilai maksimum sebesar 61.91000, memiliki nilai rata-rata sebesar 54.10886, dan standar deviasi sebesar 5.835352. Ukuran Pemda (X1) memiliki nilai minimum sebesar 13.87000, dan nilai maksimum sebesar 15.11000, memiliki nilai rata-rata sebesar 14.50864, dan standar deviasi sebesar 0.314048. Tingkat Kekayaan Pemda (X2) memiliki nilai minimum sebesar 3.500000, dan nilai maksimum sebesar 50.37000, memiliki nilai ratarata sebesar 15.25341, dan standar deviasi sebesar 11.11415. Tingkat Ketergantungan Daerah (X3) memiliki nilai minimum sebesar 39.07000, dan nilai maksimum sebesar 62.74000 , memiliki nilai rata-rata sebesar 53.51182, dan standar deviasi sebesar 5.161086. Belanja Modal (X4) memiliki nilai minimum sebesar 10.67000, dan nilai maksimum sebesar 45.14000, memiliki nilai rata-rata sebesar 24.62477, dan standar deviasi sebesar 6.789168. Temuan Audit BPK (X5) memiliki nilai minimum sebesar 0.040000, dan nilai maksimum sebesar 4.450000 , memiliki nilai rata-rata sebesar 0.551364 , dan standar deviasi sebesar 0.820007 .

\subsubsection{Analisis Regresi Data Panel}

Analisis Regresi Linier Data Panel pada penelitian ini menggunakan metode Fixed Effect. Pemilihan metode Fixed Effects sebagai metode analisis data panel pada penelitian ini sebelumnya diuji melalui uji chow dan uji hausman terlebih dahulu, sehingga akhirnya metode Fixed Effect yang paling tepat untuk menguji data panel pada penelitian ini.

Tabel 2.

Hasil Uji Regresi Data Panel dengan Metode Fixed Effect

\begin{tabular}{crrrr}
\hline Variable & Coefficient & Std. Error & t-Statistic & Prob. \\
\hline \hline C & -98.89510 & 41.84632 & -2.363293 & 0.0253 \\
X1 & 15.97796 & 3.236007 & 4.937554 & 0.0000 \\
X2 & -0.336668 & 0.055331 & -6.084638 & 0.0000 \\
X3 & -1.271954 & 0.238780 & -5.326886 & 0.0000 \\
X4 & -0.241550 & 0.119039 & -2.029164 & 0.0520 \\
X5 & 0.605021 & 0.357810 & 1.690900 & 0.1020 \\
& & & & \\
\hline \hline
\end{tabular}

Effects Specification

Cross-section fixed (dummy variables)

\begin{tabular}{lcll}
\hline \hline $\begin{array}{l}\text { R-squared } \\
\text { Adjusted }\end{array}$ & 0.824934 & Mean dependent var & 69.74376 \\
$\begin{array}{l}\text { R-squared } \\
\text { S.E. of }\end{array}$ & 0.731149 & S.D. dependent var & 40.65755 \\
regression & 3.663149 & Sum squared resid & 375.7224 \\
$\begin{array}{l}\text { F-statistic } \\
\text { Prob(F- } \\
\text { statistic) }\end{array}$ & 8.795996 & Durbin-Watson stat & 2.151755 \\
\hline \hline
\end{tabular}

Persamaan regresi dari data panel pada penelitian, sebagai berikut:

\section{$Y=-98.89510+15.97796 X 1-0.336668 X 2-$ $1.271954 X 3-0.241550 \times 4+0.605021 \times 5+0$}

\subsubsection{Hasil Pengujian Hipotesis}

\subsubsection{Uji F}

Hasil uji $\mathrm{F}$ dilihat dalam tabel prob (F-statistic) dengan asumsi 5\% (0.05), jika nilai probabilitas $<0.05$, maka dapat dikatakan terdapat pengaruh yang signifikan secara bersama-sama antara variabel bebas terhadap variabel terikat. Namun, jika nilai probabilitas > 005 maka tidak terdapat pengaruh yang signifikan secara bersama-sama antara variabel bebas terhadap 
variabel terikat. Hasil dari tabel 4.2 di atas didapat signifikansi $\mathrm{F}$ sebesar 0.000001 lebih kecil dari taraf signifikansi 0.05 , hal ini berarti bahwa $\mathrm{H}_{0}$ ditolak dan dan $\mathrm{H}_{\mathrm{a}}$ diterima. dapat disimpulkan bahwa semua variabel independen yaitu Ukuran Pemerintah Daerah (X1), Tingkat Kekayaan Daerah (X2), Tingkat Ketergantungan Daerah (X3), Belanja Modal (X4) dan Temuan Audit BPK RI (X5) secara bersama-sama memiliki pengaruh yang signifikan terhadap Akuntabilitas Kinerja Pemerintah Daerah (Y).

\subsubsection{Uji t}

Nilai $t_{\text {hitung }}$ merupakan nilai yang didapat dengan membandingkan koefisien regresi tiap variabel dengan standar error dari koefisien regresi tersebut. Kriteria keputusan dilihat nilai probabilitas dari setiap koefisien regresi masing-masing variabel independen. Hasil uji t dapat dilihat pada tabel 4.2 di atas.

a. Pengujian koefisien regresi variabel Ukuran Pemerintah Daerah Pada variabel Ukuran Pemerintah Daerah, signifikansi sebesar 0.0000 lebih kecil dari taraf signifikansi 0.05 , hal ini berarti bahwa $\mathrm{H}_{0}$ ditolak dan $\mathrm{H}_{\mathrm{a}}$ diterima, dengan demikian, Ukuran Pemerintah Daerah berpengaruh signifikan terhadap Akuntabilitas Kinerja Pemerintah Daerah Kabupaten/Kota di Provnsi Jambi.

b. Pengujian koefisien regresi variabel Tingkat Kekayaan Daerah Pada variabel Tingkat Kekayaan Daerah, signifikansi t sebesar 0.0000 lebih kecil dari taraf signifikansi 0.05, hal ini berarti bahwa $\mathrm{H}_{0}$ ditolak dan $\mathrm{H}_{\mathrm{a}}$ diterima, dengan demikian, Tingkat Kekayaan Daerah berpengaruh signifikan terhadap Akuntabilitas Kinerja Pemerintah Daerah Kabupaten/Kota di Provnsi Jambi.

c. Pengujian koefisien regresi variabel Tingkat Ketergantungan Daerah Pada variabel Tingkat Ketergantungan Daerah signifikansi t sebesar 0.0000 lebih kecil dari taraf signifikansi 0.05 , hal ini berarti bahwa $\mathrm{H}_{0}$ ditolak dan dan $\mathrm{H}_{\mathrm{a}}$ diterima, dengan demikian, Tingkat Ketergantungan Daerah berpengaruh signifikan terhadap Akuntabilitas Kinerja Pemerintah Daerah Kabupaten/Kota di Provnsi Jambi.

d. Pengujian koefisien regresi variabel Belanja ModalPada variabel Belanja Modal signifikansi t sebesar 0.0520 lebih besar dari taraf signifikansi 0.05, hal ini berarti bahwa $\mathrm{H}_{0}$ diterima dan dan $\mathrm{H}_{\mathrm{a}}$ ditolak, dengan demikian, Belanja Modal tidak berpengaruh signifikan terhadap Akuntabilitas Kinerja Pemerintah Daerah Kabupaten/Kota di Provnsi Jambi. e. Pengujian koefisien regresi variabel Temuan BPK RI Pada variabel Temuan BPK RI signifikansi t sebesar 0.1020 lebih besar dari taraf signifikansi 0.05, hal ini berarti bahwa $\mathrm{H}_{0}$ diterima dan dan $\mathrm{H}_{\mathrm{a}}$ ditolak, dengan demikian, Temuan BPK RI tidak berpengaruh signifikan terhadap Akuntabilitas Kinerja Pemerintah Daerah Kabupaten/Kota di Provnsi Jambi.

\subsubsection{Koefisien Determinasi}

Uji koefisien determinasi digunakan untuk mengetahui ada atau tidaknya hubungan antara variabel independen dan variabel dependen. Koefisien determinasi (goodness of it) dinotasikan dengan $R$ square, adalah suatu ukuran untuk menentukan baik atau tidaknya model regresi yang terestimasi. Angka ini menunjukan seberapa dekat garis regresi yang terestimasi dengan data sesungguhnya (Ghozali, 2006). Nilai $\mathrm{R}^{2}$ berkisar antara 0 hingga 1 . Nilai $R$ square sebesar 0 menunjukkan bahwa variasi dari variabel terikat tidak dapat diterangkan sama sekali oleh variabel bebas sedangkan nilai $\mathrm{R}^{2}$ sebesar 1 menunjukkan bahwa variasi dari variabel terikat secara keseluruhan dapat diterangkan oleh variabel bebas. Sedangkan nilai koefisien penentu (Adjusted $R$ Square) menunjukkan seberapa besar presentase variabel dependen dapat dijelaskan oleh variabel independen. Besarnya pengaruh Ukuran Pemerintah Daerah, Tingkat Kekayaan Daerah, Tingkat Ketergantungan Daerah, Belanja Modal dan Temuan Audit BPK RI, terhadap Akuntabilitas Kinerja Pemerintah Daerah dapat dilihat pada nilai koefisien determinasi (adjusted $R$ Square) dalam tabel 4.5 di atas. Dari tabel 4.5 dapat dilihat bahwa besarnya koefisien determinasi (Adjusted $R$ Square) yaitu sebesar 0.731149 . Besarnya pengaruh yaitu $0.731149 \times 100 \%=73.11 \%$, dan sisanya sebesar $26.89 \%$ dipengaruhi oleh faktor lain yang tidak termasuk dalam variabel penelitian.

\subsection{Pembahasan Hasil Penelitian}

\subsubsection{Pengaruh Ukuran Pemda, Tingkat Kekayaan, Tingkat Ketergantungan, Belanja Modal dan Temuan Audit BPK terhadap Akuntabilitas Kinerja Pemda}

Hipotesis pertama yang diajukan dalam penelitian ini adalah ukuran pemda, tingkat kekayaan daerah, tingkat ketergantungan daerah, belanja modal dan temuan audit BPK terhadap akuntabilitas kinerja pemda kabupaten/kota diprovinsi jambi. Berdasarkan hasil pengujian yang digambarkan dalam tabel 4.5, didapat signifikansi F sebesar 0.000001 lebih kecil dari taraf signifikansi 0.05 , hal ini berarti bahwa $\mathrm{H}_{0}$ ditolak dan dan $\mathrm{H}_{\mathrm{a}}$ diterima. Ini menunjukkan bahwa semua variabel independen berpengaruh secara simultan 
terhadap variabel dependent.Tingginya variabel independen yang mempengaruhi variabel dependen mengindikasikan bahwa 11 kabupaten/kota di Provinsi Jambi sudah cukup maksimal menggunakan atau memanfaatkan dan merencanakan dana yang telah dianggarkan secara tepat, efisien dan efektif sehingga menghasilkan output dalam hal ini penilaian akuntabilitas kinerja yang baik. Hasil ini sejalan dengan penelitian yang dilakukan oleh Mustikarini dan Fitriasari (2012); Sutaryo dan Suharyanto (2016); Harumiati dan Payamta (2014); Nurdin (2015); Qowi dan Prabowo (2017) dan bertolak belakang dengan penelitian Fonatella dan Rossieta (2014); Rianti dan Azlina (2011).

\subsubsection{Pengaruh Ukuran Pemda terhadap Akuntabilitas Kinerja Pemda}

Hasil penelitian ini menunjukkan bahwa ukuran pemerintah daerah berpengaruh positif dan signifikan terhadap akuntabilitas kinerja pemerintah daerah kabupaten/kota di Provinsi Jambi. Hal ini dibuktikan dari hasil pengujian hipotesis yang menunjukkan bahwa nilai signifikansi t pada pengaruh ukuran pemerintah daerah terhadap akuntabilitas kinerja pemerintah daerah dengan nilai yang lebih kecil dari 0.05. Dengan demikian ukuran pemerintah daerah merupakan prediktor yang baik untuk menjelaskan akuntabilitas kinerja pemerintah daerah. Berdasarkan hasil penelitian ini dibuktikan bahwa semakin besar ukuran pemerintah daerah menunjukkan bahwa akuntabilitas kinerja pemerintah daerah semakin baik. Hal ini bisa dilihat adanya peningkatan nilai aset selama tiga tahun terakhir dari tahun 2015 - 2017 yang diikuti dengan peningkatan hasil evaluasi akuntabilitas kinerja yang juga meningkat. Sebagai contoh dapat dilihat pada daerah Kabupaten Merangin dengan nilai aset pada tahun 2015 sebesar Rp.1.627.366,99 juta meningkat menjadi Rp.2.163.500,00 juta pada tahun 2017, begitupun dengan skor akuntabilitasnya yang pada tahun 2015 sebesar 48,25 meningkat menjadi 61,91 pada tahun 2017. Hasil penelitian ini sejalan dengan hasil penelitian sebelumnya yang dilakukan oleh Masdiantini dan Erawati (2016) yang mengungkapkan bahwa ukuran pemerintah daerah berpengaruh positif dan signifikan terhadap kinerja keuangan pemerintah daerah. Sementara itu, penelitian menunjukkan hasil yang berbeda dengan penelitian yang dilakukan oleh Sudarsana dan Rahardjo (2013) dan Harumiati dan Payamta (2014) yang menunjukkan bahwa ukuran pemerintah daerah tidak berpengaruh terhadap kinerja pemerintah daerah.

\subsubsection{Pengaruh Tingkat Kekayaan terhadap Akuntabilitas Kinerja Pemda}

Hasil penelitian ini memperlihatkan adanya pengaruh negatif yang signifikan dari tingkat kekayaan daerah terhadap akuntabilitas kinerja pemerintah daerah kabupaten/kota di Provinsi Jambi. Hal ini ditunjukkan oleh hasil pengujian hipotesis yang menunjukkan nilai signifikansi t lebih kecil dari taraf signifikansi 0.05 . Dengan demikian, tingkat kekayaan daerah merupakan prediktor yang baik untuk menjelaskan akuntabilitas kinerja pemerintah daerah, artinya bahwa adanya peningkatan nilai tingkat kekayaan daerah membuat terjadinya penurunan akuntabilitas kinerja pemerintah daerah di Kabupaten/Kota di Provinsi Jambi. Berdasarkan hasil penelitian ini ditunjukkan bahwa apabila tingkat kekayaan daerah semakin besar, justru akuntabilitas kinerja pemerintah semakin menurun. Hal ini misalnya bisa dilihat dari tingkat kekayaan daerah yang cukup besar seperti Kabupaten Tanjung Jabung Timur tahun 2014 dengan proporsi sebesar 38,67\%, justru hasil evaluasi atas akuntabilitas kinerja pemerintahnya dengan nilai yang cenderung rendah sebesar 50,36, sebaliknya Kabupaten Merangin yang merupakan daerah dengan tingkat kekayaan daerah hanya sebesar $6,64 \%$ pada tahun 2017 memiliki nilai akuntabilitas paling besar yaitu 60,91 . Hasil penelitian ini sejalan dengan penelitian Armaja et.al (2015) yang juga mengungkapkan bahwa tingkat kekayaan daerah yang diukur menggunakan Pendapatan Asli Daerah (PAD) berpengaruh negatif dan signifikan terhadap kinerja keuangan daerah. Sudarsana dan Rahardjo (2013), Harumiati dan Payamta (2014), Nurdin (2015), Ara et.al (2016), dan Qowi dan Prabowo (2017) memiliki hasil yang berbeda dimana penelitiannya menunjukkan bahwa, tingkat kekayaan daerah yang diproksi dengan PAD berpengaruh positif dan signifikan terhadap kinerja pemerintah daerah.

\subsubsection{Pengaruh Tingkat Ketergantungan terhadap Akuntabilitas Kinerja Pemda}

Hasil penelitian ini telah dibuktikan bahwa secara parsial tingkat ketergantungan daerah berpengaruh negatif dan signifikan terhadap akuntabilitas kinerja pemerintah daerah. Hal ini diperlihatkan oleh hasil pengujian hipotesis yang menunjukkan nilai signifikansi t pada pengaruh tingkat ketergantungan daerah terhadap akuntabilitas kinerja pemerintah daerah lebih kecil dari taraf signifikansi 0,05. Dengan demikian bahwa tingkat ketergantungan daerah mampu menjadi prediktor yang baik dalam menjelaskan akuntabilitas kinerja pemerintah daerah yang berarti bahwa semakin tinggi tingkat ketergantungan daerah akan menurunkan akuntabilitas kinerja pemerintah daerah Kabupaten/Kota di Provinsi Jambi. Penelitian ini dibuktikan berdasarkan hasil bahwa semakin besar tingkat ketergantungan daerah menunjukkan adanya penurunan akuntabilitas kinerja pemerintah daerah. Sebagai contoh Kabupaten Kerinci dengan tingkat ketergantungan sebesar $62,74 \%$ di tahun 2014 menurun pada tahun 2017 menjadi 51,33\%, 
sebaliknya skor akuntabilitasnya mengalami peningkatan dari 32,81 pada tahun 2014 menjadi 61,04 pada tahun 2017. Begitupun dengan Kabupaten Merangin dengan tingkat ketergantungan yang mengalami penurunan dari $60,98 \%$ pada tahun 2014 menjadi 54,84\% pada tahun 2017, sedangkan skor akuntabilitasnya justru meningkat dari $44,60 \%$ pada tahun 2014 menjadi $61,91 \%$ pada tahun 2017. Hasil penelitian ini sejalan dengan penelitian Armaja et.al (2015), Nurdin (2015), Fontanella dan Rossieta (2014) dan Qowi dan Prabowo (2017) yang mengungkapkan bahwa semakin besar tingkat ketergantungan pada pemerintah pusat, maka semakin rendah kinerja yang dimiliki oleh daerah tersebut. Mustikarini dan Fitriasari (2012) dan Sudarsana dan Rahardjo (2013) mempunyai hasil yang tidak mendukung penelitian ini. hasil penelitiannya, membuktikan bahwa besarnya tingkat ketergantungan daerah berpengaruh positif signifikansi terhadap kinerja pemerintah daerah.

\subsubsection{Pengaruh Belanja Modal terhadap Akuntabilitas Kinerja Pemda}

Hasil penelitian ini dibuktikan bahwa secara parsial variabel Belanja Modal tidak berpengaruh signifikan terhadap Akuntabilitas Kinerja Pemerintah Daerah Kabupaten/Kota di Provinsi Jambi Tahun 2014 - 2017, dengan nilai probabilitas sebesar 0.0520 lebih besar dari 0.05. Artinya Belanja Modal tidak mampu memprediksi peningkatan Akuntabilitas Kinerja Pemerintah Daerah. Rasio belanja modal yang diproksikan dari perbandingan antara belanja modal dengan total pendapatan pemda hasilnya terjadi ketidakstabilan setiap tahunnya, misalnya pada Kabupaten Bungo pada tahun 2014 rasio belanja modalnya sebesar $19,32 \%$, kemudian tahun 2015 menjadi 15,72\%, tahun 2016 sebesar 13,48\% dan tahun 2017 sebesar 10,67\%. lalu kepemilikan belanja modal yang besar tidak seimbang dengan akuntabilitas yang diperoleh, seperti Kabupaten Tanjabtim tahun 2014 memiliki rasio belanja modal paling tinggi sebesar $45,14 \%$ lalu mengalami penurunan sebesar $26,37 \%$ di tahun 2014, di tahun 2015 juga turun sebesar 20,84\% dan di tahun 2017 mengalami kenaikan lagi sebesar 24,83\%. Namun, skor akuntabilitas yang didapatkan Kabupaten Tanjabtim setiap tahunnya stabil. maka dapat disimpulkan tingkat realisasi belanja modal kabupaten/kota di Provinsi Jambi belum dapat dijadikan ukuran keberhasilan akuntabilitas kinerja karena realisasi belanja yang tinggi tidak mencerminkan bahwa input yang dikeluarkan pemda dalam bentuk belanja daerah dapat menghasilkan output dan outcome yang telah ditetapkan sebelumnya. Hasil penelitian ini sejalan dengan penelitian sebelumnya yang dilakukan oleh Sudarsana dan Rahardjo (2013) yang mengungkapkan bahwa belanja modal tidak berpengaruh signifikan terhadap kinerja pemerintah daerah. Sementara itu dalam penelitian Armaja et.al (2015) dan Nurdin (2015) menyebutkan bahwa tingkat belanja daerah tidak mempengaruhi akuntabilitas kinerja pemerintah.

\subsubsection{Pengaruh Temuan Audit BPK terhadap Akuntabilitas Kinerja Pemda}

Hasil penelitian ini dibuktikan bahwa secara parsial variabel Temuan BPK RI tidak berpengaruh signifikan terhadap Akuntabilitas Kinerja Pemerintah Daerah Kabupaten/Kota di Provinsi Jambi Tahun 2014 - 2017. Hal ini diperlihatkan oleh hasil pengujian hipotesis yang menunjukkan nilai signifikansi t pada pengaruh Temuan Audit BPK terhadap Akuntabilitas Kinerja Pemerintah Daerah lebih besar dari taraf signifikansi 0.05 , dimana nilai probabilitasnya 0,1020 . Temuan audit yang lebih besar berdasarkan hasil penelitian ini tidak mencerminkan rendahnya akuntabilitas kinerja pemerintah daerah kabupaten/kota di Provinsi Jambi, misalnya saja pada Kabupaten Batanghari yang memiliki temuan audit paling banyak dengan total temuan sebesar Rp 37.341.210.000., tetapi nilai akuntabilitasnya baik atau tidak rendah yakni sebesar $60,36 \%$. begitupun sebaliknya pada saat temuan audit BPK rendah tetapi justru mendapat penilaian yang baik dalam hal akuntabilitas kinerja pemerintah. Hal ini dikarenakan penilaian akuntabilitas tidak berpatokan pada temuan ketidakpatuhan dalam pelaporan keuangan daerah, tetapi lebih cenderung pada ketercapaian sasaran sesuai dengan target yang ditetapkan serta manfaatnya yang bisa dirasakan masyarakat. Hasil penelitian ini sejalan dengan hasil penelitian sebelumnya yang dilakukan oleh Nurdin (2015) dan Masdianti dan Erawati (2016) yang mengungkapkan bahwa temuan audit BPK tidak berpengaruh terhadap akuntabilitas kinerja pemerintah daerah. Sebaliknya, hasil penelitian ini tidak sesuai dengan penelitian Mustikarini dan Fitriasari (2012), Sudarsana dan Rahardjo (2013), Harumiati dan Payamta (2014), Ara et.al (2016), dan Qowi dan Prabowo (2017) yang mengungkapkan bahwa temuan audit BPK berpengaruh negatif terhadap kinerja pemerintah daerah.

\section{SIMPULAN DAN SARAN}

\subsection{Simpulan}

Berdasarkan hasil penelitian dan pembahasan yang telah dilakukan sebagaimana tersebut diatas, maka dapat ditarik kesimpulan bahwa:

1. Ukuran Pemerintah Daerah, Tingkat Kekayaan Daerah, Tingkat Ketergantungan Daerah, Belanja Modal dan Temuan Audit BPK RI secara bersama-sama (simultan) berpengaruh signifikan terhadap Akuntabilitas Kinerja Pemerintah 
Daerah. H1 terbukti karena dapat dilihat nilai Prob (F-statistic) sebesar 0,731149 < 0.05, maka hipotesis 1 (H1) terbukti atau diterima. Selanjutnya semua variabel independen tersebut mampu menjelaskan oleh nilai determinasi mencapai $73.11 \%$.

2. Ukuran Pemerintah Daerah berpengaruh positif dan signifikan terhadap Akuntabilitas Kinerja Pemerintah Daerah Kabupaten/Kota di Provinsi Jambi, H2 terbukti dikarenakan nilai probabilitas pada Ukuran Pemerintah daerah sebesar $0.0000<$ 0.05 , sehingga hipotesis $2(\mathrm{H} 2)$ yanng menyatakan ukuran pemda berpengaruh terhadap akuntabilitas kinerja pemda terbukti atau diterima. Dimana berarti bahwa setiap peningkatan Ukuran Pemerintah Daerah, akan meningkatkan Akuntabilitas Kinerja Pemerintah Daerah pada Kabupaten/Kota di Provinsi Jambi.

3. Tingkat Kekayaan Daerah berpengaruh negatif dan signifikan terhadap Akuntabilitas Kinerja Pemerintah Daerah Kabupaten/Kota di Provinsi Jambi, H3 terbukti dikarenakan nilai probabilitas pada Tingkat Kekayaan Daerah sebesar $0.0000<$ 0.05 , sehingga hipotesis $3(\mathrm{H} 3)$ yang menyatakan Tingkat Kekayaan Daerah berpengaruh terhadap Akuntabilitas Kinerja Pemda terbukti atau diterima.

4. Tingkat Ketergantungan Daerah berpengaruh negatif dan signifikan terhadap Akuntabilitas Kinerja Pemerintah Daerah Kabupaten/Kota di Provinsi Jambi, H4 terbukti dikarenakan nilai probabilitas pada Tingkat Ketergantungan Daerah sebesar $0.0000<0.05$, sehingga hipotesis 4 (H4) yang menyatakan Tingkat Ketergantungan Daerah berpengaruh terhadap Akuntabilitas Kinerja Pemda terbukti atau diterima. Hal ini berarti bahwa peningkatan Tingkat Ketergantungan Daerah mampu menjelaskan Akuntabilitas Kinerja Pemerintah Daerah pada Kabupaten/Kota di Provinsi Jambi.

5. Belanja Modal tidak berpengaruh signifikan terhadap Akuntabilitas Kinerja Pemerintah Daerah di Provinsi Jambi. H5 tidak terbukti dikarenakan nilai probabilitas pada belanja modal sebesar $0,0520>0.05$, sehingga hipotesis 5 (H5) tidak terbukti atau ditolak. Hal ini berarti bahwa peningkatan belanja modal tidak mampu menjelaskan dengan baik Akuntabilitas Kinerja Pemerintah Daerah pada Kabupaten/Kota di Provinsi Jambi.

6. Temuan BPK RI tidak berpengaruh signifikan terhadap Akuntabilitas Kinerja Pemerintah Daerah di Provinsi Jambi. H6 tidak terbukti dikarenakan nilai probabilitas pada temuan audit BPK sebesar $0.1020>0.05$, sehingga hipotesis 6 (H6) tidak terbukti atau ditolak. Hal ini berarti bahwa peningkatan Temuan BPK RI tidak mampu menjelaskan dengan baik Akuntabilitas Kinerja Pemerintah Daerah pada Kabupaten/Kota di Provinsi Jambi.

\subsection{Saran}

Berdasarkan hasil penelitian ini, maka peneliti menyumbangkan saran sebagai berikut:

1. Pemerintah Kabupaten/Kota di Provinsi Jambi agar dapat meningkatkan Akuntabilitas Kinerja dari hasil evaluasi SAKIP, karena masih ada kabupaten yang mendapatkan skor "CC" diharapkan nantinya semua Kabupaten/kota di provinsi Jambi mendapatkan nilai SAKIP "B" supaya pada saat evaluasi di tahun berikutnya Provinsi Jambi bisa meraih Predikat "BB" atau predikat tertinggi yaitu "AA". Selain itu, pemda juga harus berupaya untuk meningkatkan tingkat kekayaan daerah dengan mengoptimalkan pajak dan retribusi daerah sehingga mampu mengurangi ketergantungan daerah terhadap sumber penerimaan yang berasal dari pemerintah pusat.

2. Bagi peneliti selanjutnya yang akan melakukan penelitian yang sama, dapat mempertimbangkan hal-hal berikut :

a. Menambahkan variabel-variabel lain sebagai variabel yang mempengaruhi Akuntabilitas Kinerja Pemerintah Daerah seperti, potensi sumber daya, total penerimaan daerah, penerimaan pajak, level kapabilitas APIP, jumlah auditor APIP dan lain sebagainya.

b. Memperluas area penelitian bisa saja mencakup seluruh Indonesia atau membandingkan antara pulau bahkan provinsi.

c. Memperpanjang periode penelitian lebih dari 4 tahun, agar dapat mencerminkan kondisi kabupaten dan kota dalam jangka panjang.

\section{DAFTAR REFERENSI}

Afrian, Galang. 2016. Pengaruh Karakteristik Pemerintah Daerah, Temuan Audit (Bpk) Dan Leverage Terhadap Kinerja Pemerintah Daerah (Studi Empiris Pemerintah Daerah Kabupaten/Kota di Provinsi Riau). JOM FEKON Vol. 3 No.1 (Februari) 2016.

Anasmen. 2009. Pengaruh Belanja Modal Pemerintah Terhadap Pertumbuhan Ekonomi di Provinsi Sumatera Barat: 2000-2006. Tesis. 
Universitas Indonesia.

Ara, Samuel Christian Titiek Herwanti, dan Endar Pituringsih. 2016. Pengaruh Karakteristik Pemda Dan Temuan Audit BPK Terhadap Kinerja Pemda Kabupaten di Pulau Sumba. JAFFA Vol. 04 No. 1 April 2016 Hal. 1 - 17.

Armaja, dkk. 2015. "Pengaruh Kekayaan Daerah, Dana Perimbangan Dan Belanja Daerah Terhadap Kinerja Keuangan (Studi Pada Kabupaten/Kota Di Aceh)“. Jurnal Perspektif Ekonomi Darussalam. ISSN.2502-6976. Vol. 3, No. 2.

Damanpour, F. 1991. Organizational Innovation: A Meta Analysis of Effects of Determinants and Moderators. Academy of Management Journal, Vol.34:555-590.

Din, Muhammad dan Munawarah, Imam Ghazali, dan Tarmizi Achmad. (2017). The Follow Up of Auditing Results, Accountability of Financial Reporting and Mediating Effect of Financial Loss Rate: An Empirical Study in Indonesian Local Governments. European Research Studies Journal Volume XX, Issue 4A, 2017.

Direktorat Jendral Perimbangan Keuangan. UU No. 33 Tahun 2004 tentang Perimbangan Keuangan Antara Pemerintah Pusat dan Pemerintah Daerah.

Fitriani. 2001. Signifikansi Perbedaan Tingkat kelengkapan pengungkapan wajib dan sukarela pada laporan keuangan perusahaan public yang terdaftar di Bursa Efek Jakarta. Makalah dipresentasikan dalam Simposium Nasional Akuntansi IV.

Frankel, J. P. \& Wallen. N. E. 2008. How to Design and Evaluate Research in Education. New York : MCGraw-Hill Companies, Inc.

Fontanella, A. dan H. Rossieta. 2014. Pengaruh Desentralisasi Fiskal dan Kinerja Terhadap Akuntabilitas Pelaporan Keuangan Pemerintah daerah di Indonesia. Forum Simposium Nasional Akuntansi 17 Mataram. Diakses dari http://multiparadigma.lecture.ub.ac.id

Ghozali, Imam. 2011. "Aplikasi Analisis Multivariate Dengan Program SPSS". Semarang: Badan Penerbit Universitas Diponegoro.

Gujarati, Damodar N. 2006. Ekonometrika Dasar. Jakarta : Penerbit Erlangga.

Halim, A. Abdullah. 2006. Hubungan dan Masalah keagenan di Pemerintah Daerah. Jurnal Akuntansi pemerintah Vol.2 No.2
Harumiati, Yayuk dan Payamta. 2014. Pengaruh Karakteristik Pemerintah Daerah dan Temuan Audit Bpk Terhadap Kinerja Pemerintah Daerah Kabupaten/Kota Di Indonesia Tahun Anggaran 2011. ASSETS: Jurnal Akuntansi dan Pendidikan, Vol.3 No.2, Oktober 2014.

Jensen, M. C., and W. H. Meckling. 1976. Theory of the Firm: Managerial Behaviour, Agency Costs and Ownership Structure. Journal of Financial Economics. 3(4): 305-360.

Juliawati dkk. 2012. Pengaruh pendapatan Asli Daerah (PAD) Dan Dana Perimbangan terhadap Kinerja Keuangan Pemerintah Kabupaten/Kota Di Provinsi Aceh. Jurnal Akuntansi Pascasarjana Universitas Syiah Kuala.

Juweny, 2016. Pengaruh Karakteristik Daerah dan Temuan Audit BPK Terhadap Kinerja Pemda Provisi di Indonesia. Tesis. Program Magister Ekonomi. Universitas Lampung.

Keputusan menteri Pendayagunaan Aparatur Negara Nomor: KEP/135/M.PAN/9/2004 Tentang Pedoman Umum Evaluasi Laporan Akuntabilitas Kinerja Instansi Pemerintah. Jakarta: Kementrian Pendayagunaan Aparatur Negara

Khasanah, Nur L. 2014. Pengaruh Karakteristik, Kompleksitas, dan Temuan Audit Terhadap Tingkat Pengungkapan Laporan Keuangan Pemerintah Daerah. Skripsi. FEB UNDIP. Semarang.

Kusumawardani, Media. 2012. Pengaruh Size, Kemakmuran, Ukuran Legislatif, Leverage terhadap Kinerja Keuangan Pemerintah Daerah di Indonesia. Accounting Analysis Journal 1. Universitas Negeri Semarang.

Kwedar, Warsito, Abdul Rohman, dan Sri Handayani. 2008. Akuntansi Sektor Publik: Pendekatan Penganggaran Daerah dan Akuntansi Keuangan Daerah. Buku 2. Universitas Diponegoro. Semarang.

LAN. 2011. Instrument Akuntabilitas Bidang Auditif. Jakarta: LAN.

Lembaga Administrasi Negara. 2003. Tentang Perbaikan Pedoman Penyusunan Pelaporan Akuntabilitas Kinerja Instansi Pemerintah

Mairi, Rizani dan Syamsiar, S. Soesilo Zauhar, dan Tjahjanulin. 2014. Performance Accountability of Local Government (Case study on Presentation of Performance Accountability Report and Budget Reports on 
Office of Management of Regional Revenue, Financial and Assets in Hulu Sungai Selatan Regency). Public Policy and Administration Research. ISSN 2224-5731 (Paper) ISSN 2225-0972 (Online) Vol.4, No.8, 2014.

Mardiasmo. 2006. Perwujudan Transparansi dan Akuntabilitas Publik Melalui Akuntansi Sektor Publik: Suatu Sarana Good Governance. Jurnal Akuntansi Pemerintah Vol. 2, No. 1.

Mustikarini, W. A., Fitriasari, D. 2012. Pengaruh Karakteristik Pemerintah Daerah dan Temuan Audit BPK terhadap Kinerja Pemerintah Daerah Kabupaen/Kota di Indonesia Tahun Anggaran 2007. Proceeding Simposium Nasional Akuntansi XV: Banjarmasin.

Nachrowi, Djalal Nachrowi dan Hardius Usman. 2006. Pendekatan Populer dan Praktis Ekonometruka untuk Analisis Ekonomi dan Keuangan. Jakarta: Universitas Indonesia.

Nurdin, Fandi. 2015. Pengaruh Karakteristik Pemerintah Daerah dan Temuan Audit BPK RI Terhadap Akuntabilitas Kinerja Pemerintah Daerah. Jurnal Ilmiah Fakultas Ekonomi Universitas Brawijaya Volume 3 No. 1 Tahun 2015.

Patrick, P. A. 2007. The Determinant of Organizational Inovativeness: The Adoption of GASB 34 in Pennsylvania Local Government.Unpublished Ph.D. Dissertation. Pennsylvania: The Pennsylvania State University.

Pattawe, Abdul dan Djayani Nurdin, Nurhayati Haris, dan Mohammad Iqbal Bakri. 2017. The Effect of Local Revenue and Matching Grant on Capital Expenditures and Implications on Economic Growth in Indonesia. International Journal of Business and Management Invention. ISSN (Online): 2319 - 8028, ISSN (Print): 2319 - 801X. www.ijbmi.org Volume 6 Issue 6, June. 2017, PP-12-17.

Qowi, Rizal dan Tri Jatmiko Wahyu Prabowo. 2017. Pengaruh Karakteristik Pemerintah Daerah dan Temuan Pemeriksaan BPK Terhadap Kinerja Pemerintah Daerah Kabupaten/Kota di Indonesia Tahun Anggaran 2012. Diponegoro Journal of Accounting Volume 6, Nomor 1, Tahun 2017, Halaman 1-13.

Riantiarno, R., dan N. Azlina. 2011. Faktor-Faktor Yang Mempengaruhi Akuntabilitas Kinerja Instansi Pemerintah. Pekbis Jurnal, 3(3): 560568.

Riesty, Putu Masdianty dan Ni Made Adi Erawati.
2016. Pengaruh Ukuran Pemerintah Daerah, Kemakmuran, Intergovermental Revenue, Temuan dan Opini Audit BPK Pada Kinerja Keuangan.E-Journal Akuntansi Unud. ISSN 2302-8556 Vol. 14, No. 2, Februari 2016.

Robbins, Walter A., Austin, Kenneth R. "Disclosure Quality in Govermental Financial Reports; An Assesment of the Appropriatness of $a$ Compound Measure”. Journal of Accounting Ressearch. Vol. 24. No. 2. Pp. 412-421.

Rozy dan Wijayanti. 2014. The Influence Of The Audit Opinion, The Original Area Of Revenue (Pad) And The Equalization Fund ( $D p$ ) To Regional Financial Performance.(Empirical Studies On Local Governments That Exist In Central Java). Fakultas Ekonomi Universitas Islam Sultan Agung Semarang. Jurnal Akuntansi Indonesia, Vol. 3 No. 2 Juli 2014, Hal. 81 100 .

Sekaran, U. 2006. Metode Penelitian Untuk Bisnis 1. (4th ed).Jakarta: Salemba Empat.

Setyaningrum, Dyah dan Syafitri, Febriyani. 2012. Analisis Pengaruh Karakteristik Daerah Terhadap Tingkat pengungkapan Laporan Keuangan. Jurnal Akuntansi dan Keuangan Indonesia Vol. 9 Nomor 2.

Sri Wahyu Agustiningsih dan Sri Murni. 2017. Audit Findings, Local Government Characteristics, and Local Government Financial Statement Disclosure. 2017. Review of Integrative Business and Economics Research, Vol. 6, Issue 3.

Sudarsana, Hafidh Susila dan Shiddiq Nur Rahardjo. 2013. Pengaruh Karakteristik Pemerintah Daerah dan Temuan Audit BPK Terhadap Kinerja Pemerintah Daerah (Studi pada Pemerintah Kabupaten/Kota di Indonesia). Diponegoro Journal of Accounting Volume 2, Nomor 4, Tahun 2013, Halaman 1-13.

Sudarsana, Hafidh susila. 2013. Pengaruh Karakteristik Pemerintah Daerah dan Temuan Audit BPK Terhadap Kinerja Pemerintah Daerah (Studi Empiris Kab/Kota Seluruh Indonesia). Diponegoro Journal of Accounting Volume 2 (4), Halaman 1-13.

Sumarjo, Hendro. 2010. Pengaruh Karakteristik Pemerintah Daerah Terhadap Kinerja Keuangan Pemerintah Daeah (Studi Empiris Pada Pemerintah Daerah Kabupaten/Kota Di Indonesia. Skripsi. Surakarta: Fakultas Ekonomi, Universitas Sebelas Maret Surakarta. 
Sutaryo, Ary Suharyanto. 2016. Pengawasan Internal dan Akuntabilitas Kinerja Pemerintah Daerah di Indonesia. Simposium Nasional Akuntansi XIX, Lampung, 2016.

Suyanto. 2014. Desentralisasi Fiskal, Mempertanyakan Akuntabilitas Keuangan Pemerintah Daerah. Sekolah Tinggi Ilmu Administrasi Lembaga Administrasi Negara (STIA-LAN).

Taufiq, 2013. Sistem Informasi Manajemen Konsep Dasar, Analisis dan Metode Pengembangan. Graha Ilmu, Yogyakarta.

Turner and Hulme 1997, Governance, Administration, and Development, London: MacMillan Press.

Undang-Undang Nomor 32 Tahun 2004. Pemerintah Daerah.

Undang-Undang Republik Indonesia Nomor 15 Tahun 2004 Tentang Pemeriksaan Pengelolaan dan Tanggung Jawab Keuangan Negara.

Undang-Undang RI No. 1 Tahun 2004 tentang Pembendaharaan Negara

Undang-Undang RI No. 17 Tahun 2003 tentang Keuangan Negara

Undang-Undang RI No. 32 Tahun 2004 tentang Pemerintah Daerah 